\title{
Mechanism of anti-proliferation caused by YC-1, an indazole derivative, in cultured rat A10 vascular smooth-muscle cells
}

\author{
Sheu M. YU, ${ }^{\star}$ Z Zhi J. CHENG, ${ }^{\star}$ Jih H. GUH, $\ddagger$ Fang Y. LEE† and Sheng C. KUO† \\ *Department of Pharmacology, Chang Gung Medical College, 259 Wen-Hwa 1st Road, Kwei-San, Tao-Yuan, Taiwan and †Institute of Pharmaceutical Chemistry, \\ China Medical College, Taichung and †Pharmacological Institute, College of Medicine, National Taiwan University, Jen-Ai Road, Taipei, Taiwan
}

An indazole derivative, YC-1, was identified in this study to be capable of reversibly and effectively inhibiting proliferation of rat A10 vascular smooth-muscle cells (VSMCs) in vitro. YC-1 (1-100 $\mu \mathrm{M})$ dose-dependently inhibited $\left[{ }^{3} \mathrm{H}\right]$ thymidine incorporation into DNA in rat A10 VSMCs that were synchronized by serum depletion and then restimulated by addition of $10 \%$ foetal calf serum (FCS), whereas FCS-induced $\left[{ }^{3} \mathrm{H}\right]$ thymidine incorporation into rat synchronized endothelial cells was unaffected by this agent. The dose of YC-1 required to cause inhibition of FCS-induced proliferation was similar to that necessary for the formation of cellular cyclic GMP (cGMP). Guanylate cyclase activity in soluble fractions of VSMCs was activated by YC-1 (1-100 $\mu \mathrm{M})$, whereas cGMP-specific phosphodiesterase activity was unaffected by this compound. The anti-proliferative effect of YC-1 was mimicked by 8-bromo-cGMP, a membrane-permeable cGMP analogue, and was antagonized by KT $5823(0.2 \mu \mathrm{M})$, a selective inhibitor of protein kinase $G$. The anti-proliferative effect of YC-1 was also antagonized by Methylene Blue ( $50 \mu \mathrm{M})$, a guanylate cyclase inhibitor, and was potentiated by 3 -isobutyl1-methylxanthine $(500 \mu \mathrm{M})$, a phosphodiesterase inhibitor. These results verified that YC-1 is a direct soluble guanylate cyclase activator in A10 VSMCs, and the anti-proliferative effect of YC1 is mediated by cGMP. YC-1 still inhibited FCS-induced DNA synthesis even when added $10-18 \mathrm{~h}$ after restimulation of the serum-deprived A10 VSMCs with $10 \%$ FCS. Flow cytometry in synchronized populations revealed an acute blockage of FCSinducible cell-cycle progression at a point in the $G_{1} / S$-phase in YC-1 $(100 \mu \mathrm{M})$-treated cells. The inhibition of proliferation by YC-1 was demonstrated to be independent of cell damage, as documented by several criteria of cell viability. In conclusion, YC-1 reversibly and effectively inhibited the proliferation of VSMCs, suggesting that it has potential as a therapeutic agent in the prevention of vascular diseases.

\section{INTRODUCTION}

Proliferation of vascular smooth-muscle cells (VSMCs) is a prominent feature of vascular response to mechanical injury $[1,2]$. Abnormal proliferation of VSMCs is a major component of vascular disease, including atherosclerosis, vascular rejection and restenosis after angioplasty [3,4]. Therefore modulation of proliferation has critical therapeutic implications for vascular disease. An important therapeutic aim is inhibition of VSMC proliferation without interfering with endothelial or other cell proliferation. Theoretically, a selective inhibitor of VSMC proliferation is therefore required [5]. Several agents that suppress VSMC proliferation have already been identified: prostaglandins $E_{1}, E_{2}[6,7]$, heparin [8], interferon $\alpha$ [9], $\beta$-transforming growth factor [10] and protein kinase $C$ activator [11]. However, no significant inhibition of atherosclerosis or restenosis has been achieved with the above agents [5].

Much of the work involving inhibitors of VSMC proliferation has been carried out on VSMCs in culture. This technique is ideally suited to the study of action mechanisms of inhibitors and the cell cycle. A10 cells, isolated and characterized by Kimes and Brandt [12] from rat aorta, have many of the properties of smooth-muscles cells in culture. These cells have some advantages over primary cultured cells, i.e. flexibility in handling and morphological and biochemical stability after multiple passages [13]. In our studies, the characteristics of stimulation of DNA synthesis by mitogens and the proliferative properties of serum remained stable from passage 16 through to passage 32 .

It has recently been discovered that NO and nitrovasodilators have an inhibitory effect on the proliferation of VSMCs $[14,15]$ by a cyclic GMP (cGMP)-mediated mechanism. In a large-scale screening test, we found that 1-benzyl-3-(5'-hydroxymethyl-2'furyl)indazole (YC-1), an indazole derivative (Figure 1), exerted vasorelaxing effects in rat aorta as well as anti-aggregatory effects in platelets, both of which protect the vascular wall against arteriosclerotic changes. The vasorelaxation and antiaggregatory effects of YC-1 were mediated by a cGMP-controlled pathway [16]. In this study, YC-1 was found to inhibit proliferation of rat A10 VSMCs; an attempt was therefore made to characterize its modes of action. This is the first report to demonstrate that YC-1 potentially inhibits proliferation of VSMCs by activating soluble guanylate cyclase.

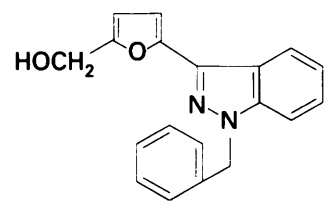

Figure 1 Chemical structure of YC-1

Abbreviations used: YC-1, 1-benzyl-3-(5'-hydroxymethyl-2'-furyl)indazole; cGMP, cyclic GMP; 8-Br-cGMP, 8-bromo-cGMP; FCS, foetal calf serum; VSMC, vascular smooth-muscle cell; IBMX, 3-isobutyl-1-methylxanthine; DMEM, Dulbecco's modified Eagle's medium; SNP, sodium nitroprusside; KHS, Krebs-Henseleit solution.

$\S$ To whom correspondence should be addressed. 


\section{MATERIALS AND METHODS}

\section{Materials}

YC-1 (Figure 1) was chemically synthesized as described previously [17]. Dulbecco's modified Eagle's medium (DMEM), foetal calf serum (FCS) and all other tissue culture reagents were obtained from Grand Island Biological Co. (Gibco-BRL). $\left[{ }^{3} \mathrm{H}\right]$ Thymidine, $\left[{ }^{3} \mathrm{H}\right] \mathrm{cGMP},\left[\alpha^{32} \mathrm{P}\right] \mathrm{GTP}$ and cGMP e.l.i.s.a. kit were from Amersham (Bucks., U.K.). KT 5823 was obtained from Biomol. Protein dye reagents were purchased from BioRad. Sodium nitroprusside (SNP), 3-isobutyl-1-methylxanthine (IBMX), 8-bromo-cGMP (8-Br-cGMP), Trypan Blue, Methylene Blue and all other chemical reagents were from Sigma Chemical Co. (St. Louis, MO, U.S.A.).

\section{Cell cultures}

Rat A10 VSMCs were obtained from the American Type Culture Collection (ATCC). A10 cells were grown in DMEM containing $10 \%$ FCS, 100 units $/ \mathrm{ml}$ penicillin $\mathrm{G}$ and $100 \mu \mathrm{g} / \mathrm{ml}$ streptomycin sulphate at $37{ }^{\circ} \mathrm{C}$ in a humidified $5 \% \mathrm{CO}_{2}$ in air atmosphere. Rat aortic endothelial cells were isolated from the thoracic portion by digestion in collagenase in serum-free M199 medium for $7 \mathrm{~min}$ at $37^{\circ} \mathrm{C}$ [18]. The cells were collected by centrifugation and the pellet was resuspended in M199 containing $10 \%$ FCS.

\section{[3 H]Thymidine incorporation}

Cells were finally grown in 24 -well plates $\left(2.5 \times 10^{4}\right.$ cells $/$ well $)$, washed with Krebs-Henseleit solution (KHS) $(117.5 \mathrm{mM} \mathrm{NaCl}$, $5.6 \mathrm{mM} \mathrm{KCl}, 1.18 \mathrm{mM} \mathrm{MgSO}, 1.2 \mathrm{mM} \mathrm{NaH}_{2} \mathrm{PO}_{4}, 25.0 \mathrm{mM}$ $\mathrm{NaHCO}_{3}, 5.5 \mathrm{mM}$ glucose, $25.0 \mathrm{mM}$ Hepes and $2.5 \mathrm{mM} \mathrm{CaCl}$ then incubated in FCS-free DMEM for $48 \mathrm{~h}$ to induce quiescence at $37^{\circ} \mathrm{C}$. To investigate the effect of $\mathrm{YC}-1$ on proliferation and cell cycle, quiescent cells were cultured for $20 \mathrm{~h}$ in medium supplemented with or without $10 \%$ FCS, in the presence or absence of experimental agents. Finally, cells were incubated for $2 \mathrm{~h}$ in freshly prepared media that were additionally supplemented with $\left[{ }^{3} \mathrm{H}\right]$ thymidine $(1 \mu \mathrm{Ci} / \mathrm{ml})$ to measure DNA synthesis by thymidine incorporation $[19,20]$. The experiments were terminated by washing cells with KHS, precipitation of acidinsoluble material with $10 \%$ trichloroacetic acid and extraction of DNA with $0.1 \mathrm{M} \mathrm{NaOH}$. The precipitates were collected on Whatman GF/B filters, which were cut up and counted in a scintillation counter.

\section{Measurement of CGMP}

cGMP concentrations in A10 VSMCs were assayed as previously described by Kariya et al. [21]. At confluence, monolayer cells were incubated with YC-1 in the presence of $0.1 \mathrm{mM}$ IBMX for $10 \mathrm{~min}$. Incubation was terminated by the addition of $0.1 \mathrm{M}$ $\mathrm{HCl}$. After four extractions with ether, the supernatant was assayed by using a cGMP e.l.i.s.a. kit (Amersham).

\section{Dotermination of soluble guanylate cyclase activity}

A10 cells were resuspended in ice-cold $50 \mathrm{mM}$ Tris/ $\mathrm{HCl}$ buffer (pH 7.4) and sonicated at $4{ }^{\circ} \mathrm{C}$ for $10 \mathrm{~s}$ bursts (Sonicator W220F). Homogenates were centrifuged at $40000 \mathrm{~g}$ for $10 \mathrm{~min}$ and the resulting supernatant fraction was used for guanylate cyclase determination $[22,23]$. The incubation mixture $(100 \mu \mathrm{l}$ total volume) contained $0.2 \mathrm{mM}$ GTP, $1 \times 10^{6}$ c.p.m. of $\left[\alpha^{32} \mathrm{P}\right] \mathrm{GTP}$, $5 \mathrm{mM} \mathrm{MgCl} 2,2.5 \mathrm{mM}$ cGMP, $10 \mathrm{mM}$ dithiothreitol, $15 \mathrm{mM}$ creatine phosphate, $0.2 \mathrm{mg} / \mathrm{ml}$ creatine kinase, with or without
YC-1 in a $50 \mathrm{mM}$ Tris/ $\mathrm{HCl}$ buffer, $\mathrm{pH}$ 7.4. Incubations were carried out at $37^{\circ} \mathrm{C}$ for $10 \mathrm{~min}$ with $50 \mu \mathrm{l}(1 \mathrm{mg} / \mathrm{ml})$ of enzyme preparation, and terminated by adding $0.5 \mathrm{M} \mathrm{HCl}$ and $1 \mathrm{mM}$ imidazole. The tubes were then heated to $100^{\circ} \mathrm{C}$ for $3 \mathrm{~min}$ in an electric heating block and cooled in an ice-bath. The supernatant was applied to a neutral alumina column to isolate cGMP for radioassay of ${ }^{32} \mathrm{P}$ and ${ }^{3} \mathrm{H}$. Protein was determined by using Bradford reagent (Bio-Rad) [24].

\section{Determination of CGMP-specific phosphodiesterase activity}

The supernatant fraction of A10 VSMC lysate was used for cGMP-specific phosphodiesterase determination [25,26]. The crude cytosolic enzyme $(8.4 \mathrm{mg} / \mathrm{ml})$ was incubated with cGMP (10 $\mu \mathrm{M}$, containing $0.1 \mu \mathrm{Ci}$ of $\left.\left[{ }^{3} \mathrm{H}\right] \mathrm{cGMP}\right)$ and compound in a final volume of $0.4 \mathrm{ml}$ (buffer was $50 \mathrm{mM}$ Tris $/ \mathrm{HCl}, 5 \mathrm{mM}$ $\mathrm{MgCl}_{2}, \mathrm{pH}$ 7.4). After $30 \mathrm{~min}$ at $25^{\circ} \mathrm{C}$, the samples were heated to $100^{\circ} \mathrm{C}$ for $1 \mathrm{~min}$ before cooling. Snake (Ophiophagus hannah) venom $(0.1 \mathrm{ml} ; 1 \mathrm{mg} / \mathrm{ml})$ was then added for $30 \mathrm{~min}$ to convert the 5'-GMP into the uncharged nucleoside, guanosine. Anionexchange resin (Dowex 1; $1 \mathrm{ml}$ ) was added to bind all of the unconverted cGMP. After centrifugation, an aliquot $(0.5 \mathrm{ml})$ of the supernatant was removed for quantification in a liquidscintillation counter.

\section{Cell-cycle analysis}

To estimate the proportions of cells in different phases of the cell cycle, cellular DNA contents were measured by flow cytometry as described by March et al. [27]. Briefly, cells $\left(2 \times 10^{6}\right.$ cells $\left./ \mathrm{ml}\right)$ were fixed in $70 \%$ ethanol (in PBS) in ice for $30 \mathrm{~min}$ and then resuspended in PBS containing $40 \mu \mathrm{g} / \mathrm{ml}$ propidium iodide and $0.1 \mathrm{mg} / \mathrm{ml} \mathrm{RNAase} \mathrm{(Boehringer,} \mathrm{Mannheim,} \mathrm{Germany).} \mathrm{After}$ $30 \mathrm{~min}$ at $37^{\circ} \mathrm{C}, 2 \times 10^{4}$ cells were analysed on a FACstar cytofluorimeter (Becton-Dickinson, San Jose, CA, U.S.A.) exciting at $488 \mathrm{~nm}$ and sensing at $585 \mathrm{~nm}$.

\section{Cell growth}

To determine the effect of YC-1 on cell growth, cells $\left(2.5 \times 10^{3} /\right.$ well) were cultured for $48 \mathrm{~h}$ in FCS-free medium to induce quiescence. They were then cultured for 6 days in medium supplemented with $10 \% \mathrm{FCS}$, in the presence or absence of YC-1. Culture medium and YC-1 were changed daily and cell numbers were determined by dissociation of adherent cells with trypsin and counting in a haemocytometer.

\section{Data analysis}

Results are expressed as means \pm S.E.M. A one-way analysis of variance was used for multiple comparison, and, if there was significant variation between treatment groups, the mean values for inhibitors were compared with those for controls by using Student's $t$ test; $P$ values of less than 0.05 were considered to be statistically significant.

\section{RESULTS AND DISCUSSION}

\section{Effects of YC-1 on mitogen-Induced $\left[{ }^{3} \mathrm{H}\right]$ thymidine incorporation}

Initial studies were designed to characterize the ability of mitogens to stimulate incorporation of $\left[{ }^{3} \mathrm{H}\right]$ thymidine into DNA as an indicator of proliferation $[28,29]$. YC-1 $(1-100 \mu \mathrm{M})$ dosedependently inhibited $\left[{ }^{3} \mathrm{H}\right]$ thymidine incorporation into DNA in rat A10 VSMCs that were synchronized by $48 \mathrm{~h}$ serum depletion and then stimulated by addition of $10 \% \mathrm{FCS}$, with $\mathrm{IC}_{50}$ values of $10.5 \pm 2.9 \mu \mathrm{M}$ (Figure 2). The inhibitory effect of YC-1 was 


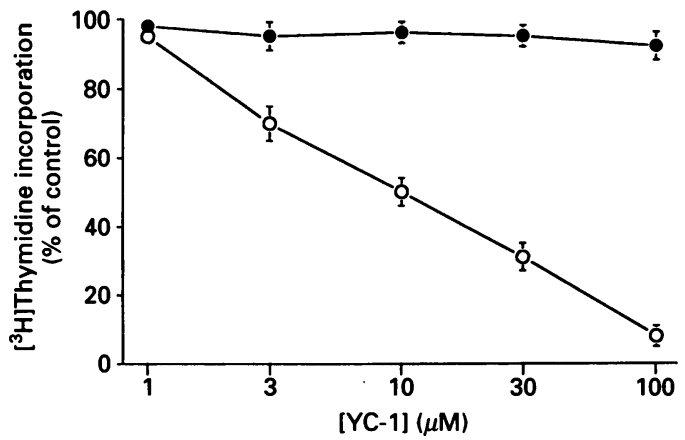

Figure 2 Effects of YC-1 on serum-induced $\left[{ }^{3} \mathrm{H}\right]$ thymidine incorporation in A10 VSMCs and endothelial cells

Dose-response curve for the inhibition of FCS-induced $\left[{ }^{3} \mathrm{H}\right]$ thymidine incorporation by $\mathrm{YC}-1$. Quiescent A10 VSMCs $(O)$ or endothelial cells $(O)$ were incubated with various concentrations of YC-1 and stimulated with $10 \%$ FCS for $20 \mathrm{~h}$. Results are means \pm S.E.M. of four to six separate experiments, each performed in quadruplicate, and are expressed as percentage of control, defined as $\left[^{3} \mathrm{H}\right]$ thymidine incorporation in the presence of $10 \%$ FCS only (in VSMCs it was $48500 \pm 800$ c.p.m./well, and in endothelial cells $39700 \pm 890$ c.p.m./well).

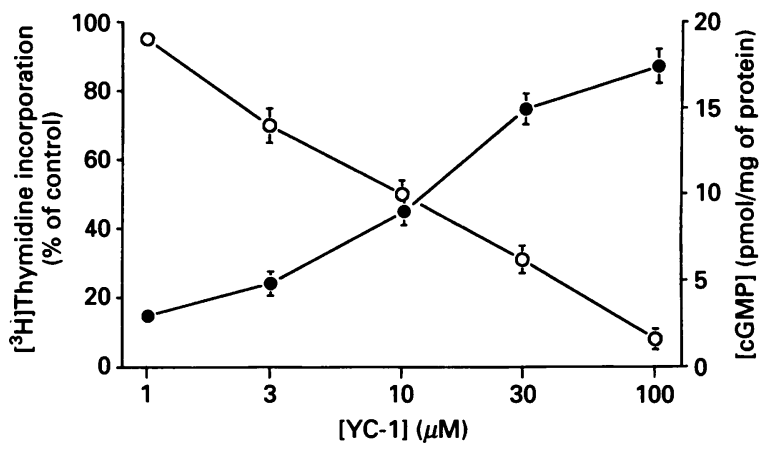

Figure 3 Dose-dependent inhibition of serum-induced proliferation and dose-dependent formation of CGMP by YC-1

Quiescent A10 VSMCs were incubated with various concentrations of YC-1 and then stimulated with $10 \%$ FCS for $20 \mathrm{~h} ;\left[^{3} \mathrm{H}\right]$ thymidine incorporation was determined $(\mathrm{O})$. For the assay of cGMP formation, the cells were treated with YC-1 $(1-100 \mu \mathrm{M})$ for $10 \mathrm{~min}$ at $37^{\circ} \mathrm{C}(\mathbf{O})$ Cellular cGMP levels were determined by using a cGMP e.l.i.s.a. kit. Data are expressed as means \pm S.E.M. of four separate experiments (each in quadruplicate).

Table 1 Stimulation of guanylate cyclase activity in the soluble fraction of vsMCs by YC-1

Soluble fractions of VSMCs were incubated with various concentrations of SNP or YC-1 for 10 min and then assayed for guanylate cyclase activity as described in the Materials and methods section. Data are expressed as means \pm S.E.M. $(n=6){ }^{*} P<0.05,{ }^{* \star} P<0.01$, *** $P<0.001$, compared with basal activity

\begin{tabular}{lrl}
\hline Addition & $\begin{array}{l}\text { Concn. } \\
(\mu \mathrm{M})\end{array}$ & $\begin{array}{l}\text { Guanylate cyclase activity } \\
(\mathrm{pmol} / \mathrm{min} \text { per } \mathrm{mg} \text { of protein) }\end{array}$ \\
\hline None (basal) & & $26.5 \pm 7.3$ \\
SNP & 10 & $50.5 \pm 6.9^{*}$ \\
& 30 & $70.8 \pm 8.8^{* *}$ \\
YC-1 & 100 & $94.0 \pm 7.6^{* \star *}$ \\
& 1 & $33.0 \pm 5.0$ \\
& 3 & $47.6 \pm 5.1^{*}$ \\
& 10 & $61.4 \pm 7.6^{* *}$ \\
& 30 & $77.3 \pm 6.9^{* \star \star}$ \\
& 100 & $92.9 \pm 8.8^{* * *}$
\end{tabular}

\section{Table 2 Effects of IBMX and YC-1 on VSMC CGMP-specific phospho-} diesterase activity

Cell extracts were incubated with various concentrations of IBMX or YC-1 for $10 \mathrm{~min}$ and then assayed for enzyme activity as described in the Materials and methods section. Values are presented as means \pm S.E.M. $(n=4)$. ${ }^{*} P<0.05,{ }^{\star *} P<0.001$, compared with basal activity.

\begin{tabular}{lcc}
\hline Addition & $\begin{array}{l}\text { Concn. } \\
(\mu \mathrm{M})\end{array}$ & $\begin{array}{l}\text { Phosphodiesterase activity } \\
\text { (c.p.m.) }\end{array}$ \\
\hline None (basal) & & $10655 \pm 599$ \\
IBMX & 100 & $8933 \pm 413^{*}$ \\
& 500 & $7888 \pm 299^{* *}$ \\
YC-1 & 1000 & $5000 \pm 281^{* *}$ \\
& 30 & $10196 \pm 188$ \\
& 100 & $10385 \pm 117$
\end{tabular}

fully reversible, and $\left[{ }^{3} \mathrm{H}\right]$ thymidine incorporation recovered within $24 \mathrm{~h}$ of the removal of $100 \mu \mathrm{M} \mathrm{YC}-1$ (results not shown). YC-1 also caused inhibition of platelet-derived growth factor/BB (10 ng/ml)-, 5-hydroxytryptamine $(10 \mu \mathrm{M})$ - and ADP $(10 \mu \mathrm{M})$ stimulated DNA synthesis in A10 VSMCs with similar IC $_{50}$ values: $14.6 \pm 4.7,16.4 \pm 3.7$ and $18.1 \pm 4.0 \mu \mathrm{M}$ respectively. These results demonstrate that YC-1, an indazole derivative, reversibly and effectively inhibits proliferation of rat A10 VSMCs, which is a prominent feature of vascular response to mechanical injury.

YC-1 $(1-100 \mu \mathrm{M})$ did not inhibit $\left[{ }^{3} \mathrm{H}\right]$ thymidine incorporation in FCS-stimulated rat aortic endothelial cells (Figure 2). However, high concentrations of YC-1 $(300 \mu \mathrm{M})$ did inhibit $\left[{ }^{3} \mathrm{H}\right]$ thymidine incorporation in FCS-stimulated endothelial cells by $23 \pm 4 \%$. SNP $(1 \mathrm{mM})$ did inhibit $\left[{ }^{3} \mathrm{H}\right]$ thymidine incorporation in FCS-stimulated endothelial cells by $26 \pm 5 \%$. It has been postulated that one of the functions of endothelial cells is to maintain the mitogenic quiescence of the underlying medial VSMCs [15,32]. A major therapeutic aim is to inhibit VSMC proliferation without interfering with endothelial-cell proliferation [30,31]. YC-1 $(1-100 \mu \mathrm{M})$, which selectively inhibits A10 VSMC proliferation without affecting endothelial-cell proliferation, might therefore be expected to prevent or inhibit the progress of vascular diseases. Yang et al. [33] have reported that donors of NO inhibit the proliferation of cultures of bovine foetal aortic, human umbilical-vein and mouse lymph-nodevessel endothelial cells, but Ziche et al. [34] reported that exogenous NO enhances the proliferation of this cell type cultured from bovine coronary post-capillary venules. The exact reason for the discrepancy between these results is unclear, but it may be due to differences in the cell lines and experimental conditions used.

\section{Effects of YC-1 on CGMP formation and guanylate cyclase activation}

The dose of YC-1 required to inhibit FCS-induced proliferation was similar to that necessary for cGMP formation (Figure 3). The site of action of YC-1-induced cGMP formation was clarified by determining the activities of guanylate cyclase and cGMPspecific phosphodiesterase. As shown in Table 1, dose-dependent increases in soluble guanylate cyclase activity were observed in YC-1 and SNP-treated VSMCs. cGMP-specific phosphodiesterase activity was inhibited by IBMX, whereas YC-1 $(100 \mu \mathrm{M})$ had no effect on this enzyme activity in A10 VSMCs (Table 2). These results demonstrate that YC-1 is an activator of soluble guanylate cyclase in VSMCs. 


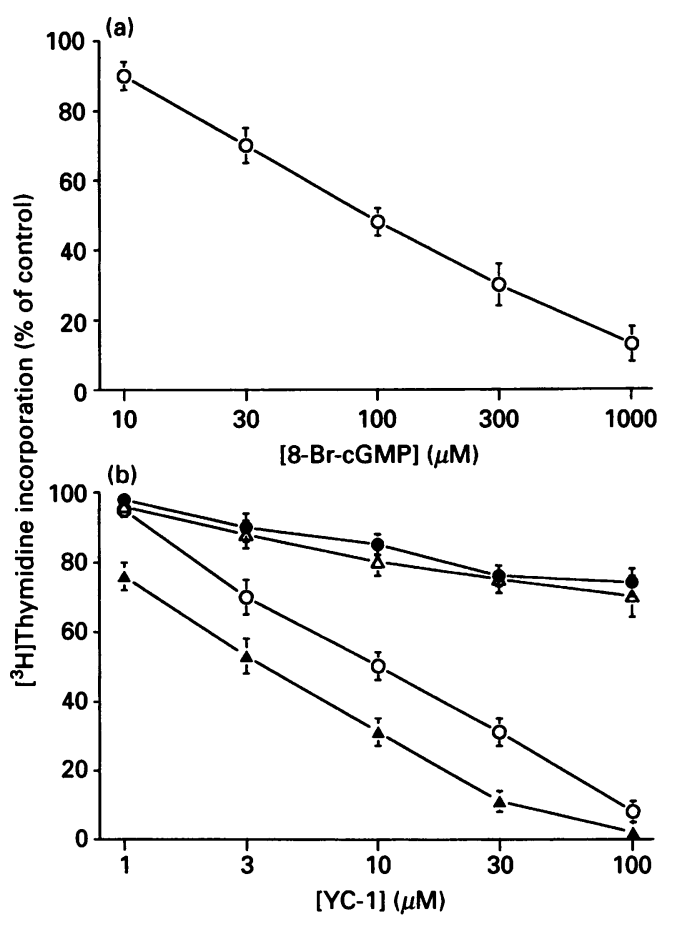

Figure 4 Effects of 8-Br-cGMP, KT 5823, Methylene Blue and IBMX on YC-1-induced anti-proliferation

Quiescent A10 VSMCs were stimulated with $10 \%$ FCS at various concentrations of 8-Br-CGMP (a), or (b) YC-1 alone (O), YC-1 combined with KT $5823(0.2 \mu \mathrm{M})(\mathrm{O})$, YC-1 combined with Methylene Blue $(50 \mu \mathrm{M})(\triangle)$ or $\mathrm{YC}-1$ combined with IBMX $(500 \mu \mathrm{M})(\boldsymbol{\Delta})$ for $20 \mathrm{~h}$. Results are expressed as means \pm S.E.M. of three separate experiments (each performed in quadruplicate). FCS-stimulated $\left[{ }^{3} \mathrm{H}\right]$ thymidine incorporation: $47000 \pm 650$ c.p.m./well.

\section{Effects of 8-Br-cGMP, KT 5823, Methylene Blue and IBMX on YC-1-induced anti-prolliferation}

The anti-proliferative effect of YC-1 was mimicked by $8-\mathrm{Br}$ cGMP (10-1000 $\mu \mathrm{M})$, a membrane-permeable cGMP analogue, as shown in Figure 4(a) and antagonized by KT $5823(0.2 \mu \mathrm{M})$, a selective inhibitor of protein kinase G [35] (Figure 4b), which by itself did not affect cell proliferation. Methylene Blue $(50 \mu \mathrm{M})$, a guanylate cyclase inhibitor [36], by itself had only a slight effect on FCS-induced proliferation. However, as indicated in Figure 4(b), the dose-response curve for YC-1-induced inhibition of proliferation was shifted to the right, indicating antagonism of the anti-proliferative activity of YC-1 by Methylene Blue. IBMX (500 $\mu \mathrm{M})$, a non-selective cyclic nucleotide phosphodiesterase inhibitor, alone caused a $5 \%$ decrease in FCS-stimulated thymidine incorporation; however, as shown in Figure 4(b) it caused significant potentiation of the anti-proliferative activity of YC-1, particularly at low concentrations of the latter. These results verify that guanylate cyclase was the effector of YC-1, and the anti-proliferative effect of YC-1 was mediated by cGMP. cGMP has been reported to inhibit the proliferation of VSMCs [32,37], but the molecular mechanisms of this anti-proliferative action remain to be clarified. Inhibition of proliferation of cGMP-elevating agents (e.g. SNP and 3morpholinosydonimine) at concentrations higher than those required for vasorelaxation $[15,38,39]$ was also observed in this study. Reasons for this discrepancy may include instability of these agents [40] and binding to serum [41]. However, inhibition of proliferation by YC-1 at concentrations of $1-100 \mu \mathrm{M}$ was

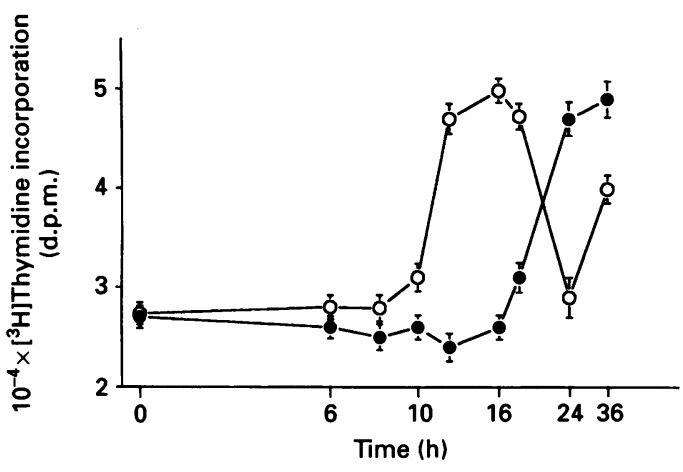

Figure 5 Chronological analysis of effects of YC-1 on FCS-induced DNA synthesis

Quiescent cultures of A10 VSMCs were stimulated with $10 \%$ FCS for $36 \mathrm{~h}$. During this incubation, dimethyl suphoxide $(0.05 \%$; control) $(O)$ or YC-1 $(100 \mu \mathrm{M})(0)$ was added at the indicated times and incubations were continued for $36 \mathrm{~h}$. [ $\left.{ }^{3} \mathrm{H}\right]$ Thymidine was added $2 \mathrm{~h}$ before the incubations were terminated. Results are means \pm S.E.M. of four experiments.

similar to that causing vasorelaxation in the rat aorta. This phenomenon demonstrates that YC-1 is fairly stable over a $24 \mathrm{~h}$ culture period and has very weak plasma-protein-binding properties.

\section{Effects of YC-1 on the cell cycle in synchronized populations}

To ensure that the cells were capable of synchronously reentering the cell cycle after $48 \mathrm{~h}$ of serum starvation, cellular stimulation of $\left[{ }^{3} \mathrm{H}\right]$ thymidine incorporation was determined (Figure 5). DNA synthesis increased slowly, reached its maximum within $16 \mathrm{~h}$, and declined soon after. The $\mathrm{G}_{1}$-phase can be confined to the first $8 \mathrm{~h}$, the S-phase between 10 and $18 \mathrm{~h}$, and the $\mathrm{G}_{2} / \mathrm{M}$-phase between 20 and $26 \mathrm{~h}$. To clarify the mode of antiproliferative action of YC-1, the relationship between the time of addition of YC-1 and its inhibitory action on FCS-induced DNA synthesis was examined. As shown in Figure 5, YC-1 still inhibited FCS-induced DNA synthesis even when added $10-18 \mathrm{~h}$ after the addition of FCS. This result implies that YC-1 inhibits FCSinduced proliferation by inhibiting progression from the $\mathrm{G}_{1}$ - to the S-phase of the cell cycle. Furthermore, the present flowcytometric results demonstrate that YC-1 inhibits progression from the $G_{1} / S$-phase of the cell cycle. After a $48 \mathrm{~h}$ exposure to serum-free medium, most VSMCs remained in the $\mathrm{G}_{0}$-phase of the cell cycle (Figure 6a). After replacement of serum-free medium with DMEM containing $10 \%$ FCS, the emergence of cells into and through the S-phase was observed by flow cytometry using quantitative DNA staining with propidium iodide (Figure 6b). The majority of cycling cells were found to progress through the S-phase approximately $18 \mathrm{~h}$ after serum repletion (Figure $6 \mathrm{~b}$ ). YC-1-treated cells showed an acute blockage of cell cycle progression occurring at the $G_{1} / S$-phase; no increase in DNA content was observed in cells stimulated by serum in the presence of YC-1 $(100 \mu \mathrm{M})$ (Figure 6c). This result is consistent with cGMP-elevating vasodilators exerting their anti-proliferative action by inhibiting progression from the $G_{1}$ - to the S-phase of the cell cycle $[15,21,32]$. Our results are also consistent with previous work $[7,11,32]$ showing that elevated cGMP concentrations at a latter stage of the $G_{1}$-phase of the cell cycle would be necessary to inhibit proliferation. 


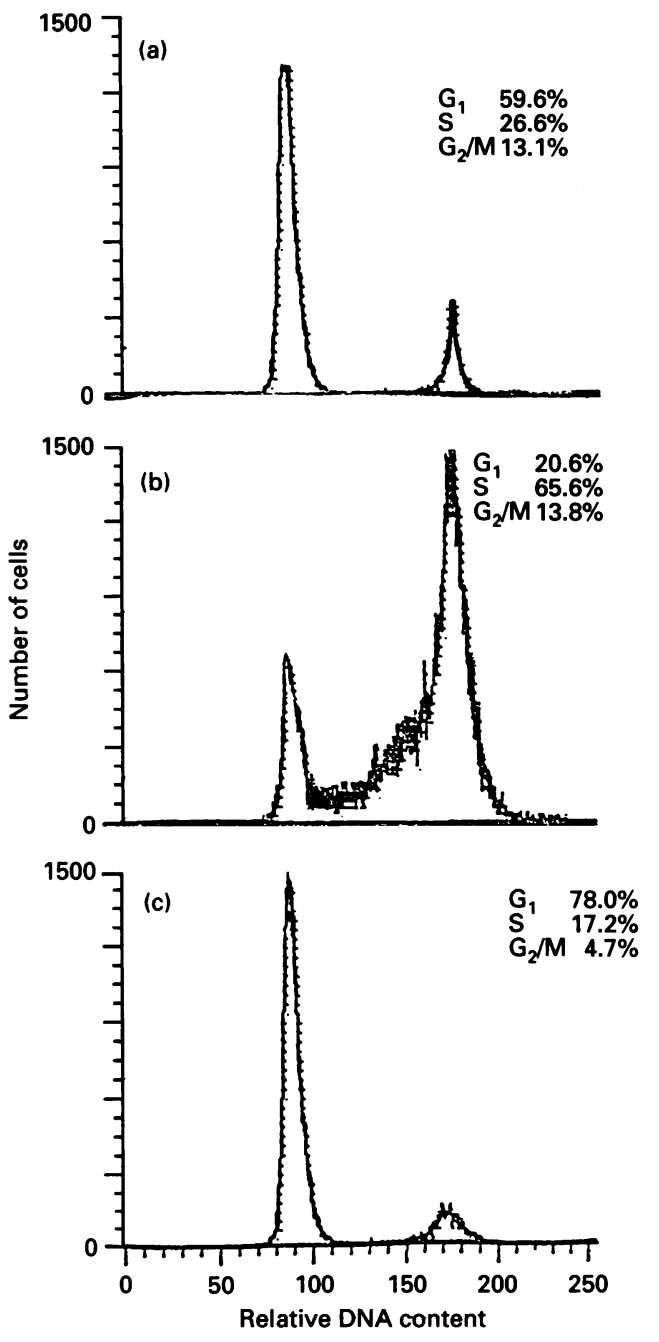

Figure 6 Effect of YC-1 on the cell cycle in synchronized cells

Cell-cycle progression was evaluated by flow-cytometric determination of DNA content in synchronized subconfluent A10 VSMCs evaluated at $0 \mathrm{~h}$ (control) (a) and $18 \mathrm{~h}$ after serum repletion in the absence (b) or presence (c) of YC-1 $(100 \mu \mathrm{M})$. Individual nuclear DNA content as reflected by fluorescence intensity of incorporated propidium iodide is plotted as a histogram depicting relative cell numbers at each intensity. The percentage of cells in each phase is indicated.

\section{Effects of YC-1 on cell growth}

Cell counting was used to evaluate the effects of YC-1 on cell growth. This revealed prolonged stasis of growth of subconfluent cells caused by YC-1 (100 $\mu \mathrm{M})$ (Figure 7); a lethal effect on the cell population was discounted as ascertained by Trypan Blue exclusion.

To examine the possibility that YC-1 might be toxic to VSMCs, the following series of experiments was performed. (a) The number of the cells present in the supernatant was determined daily for 4 days, in both the presence and absence of $100 \mu \mathrm{M}$ YC-1. Although this concentration of YC-1 caused significant inhibition of cell growth (more than $90 \%$ ), less than $5 \%$ of the cells were found to be present in the supernatant during any portion of the culture period. Thus detachment and loss of cells did not account for the inhibition of cell proliferation. (b) Incubation of A10 VSMCs for $24 \mathrm{~h}$ with YC-1 $(100 \mu \mathrm{M})$ also caused no significant cell loss: the number of cells was

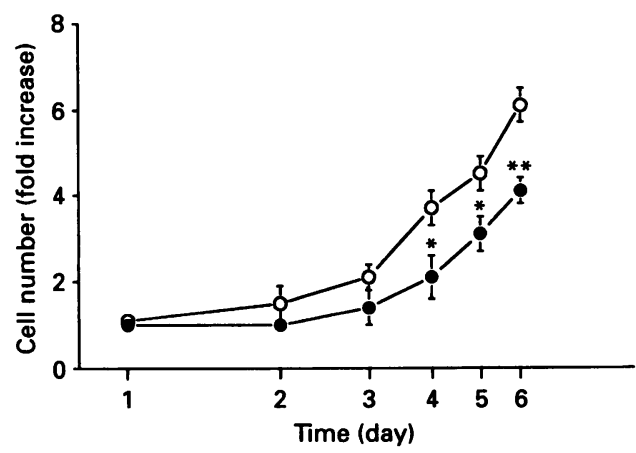

Figure 7 Inhibition of VSMC growth by YC-1

VSMCs were seeded on 12-well plates (density was $2.5 \times 10^{3} /$ well) and counted in Trypan Blue at subsequent time points. Dimethyl sulphoxide $(\mathrm{O})$ or $\mathrm{YC}-1(100 \mu \mathrm{M})(\mathrm{O})$ was added and the mixture incubated for 6 days in medium supplemented with 10\% FCS. Results represent means \pm S.E.M. of three separate experiments, each in quadruplicate, and are expressed as the fold increase in cell number relative to that on day 0 of the experiment. The difference between each of the growth curves in the presence of $\mathrm{YC}-1$ and control was significant $\left({ }^{*} P<0.05\right.$, $* * P<0.01$ ) by analysis of variance.

$2.8( \pm 0.2) \times 10^{3}$ in control wells and $3.0( \pm 0.3) \times 10^{3}$ in $\mathrm{YC}-1$ $(100 \mu \mathrm{M})$-treated wells. Furthermore, no significant release of lactate dehydrogenase was observed in this experiment, again indicating that, in short-term incubations, even higher concentrations of YC-1 did not induce cell damage. (c) Less than $1 \%$ of the cells treated with YC-1 $(100 \mu \mathrm{M})$ for $24 \mathrm{~h}$ stained with Trypan Blue.

In conclusion, this study demonstrates that YC-1 inhibits VSMC proliferation via the guanylate cyclase/cGMP pathway. and by inhibiting progression from the $G_{1}$ - to the S-phase of the cell cycle. The anti-proliferative effect of YC-1 is unlikely to cause cell toxicity, therefore it may have potential as a therapeutic agent for the prevention of vascular diseases.

This work was supported by research grant CMRP 377 from Chang Gung Medical Research Foundation and the National Science of the Republic of China (NSC 840412-B182-036).

\section{REFERENCES}

1 Campbell, G. R. and Campbell, J. H. (1985) Exp. Mol. Pathol. 42, 139-162

2 Ip. J. H., Fuster, V., Badimon, L., Badimon, J., Taubman, M. B. and Chesebro, J. H. (1990) J. Am. Coll. Cardiol. 15, 1667-1687

3 Ross, R. and Glomset, J. A. (1973) Science 180, 1332-1339

4 Ross, R. (1986) N. Engl. J. Med. 314, 488-500

5 Weissberg, P. L., Grainger, D. J., Shanahan, C. M. and Metcalfe, J. C. (1993) Circ. Res. 27, 1191-1198

6 Nilsson, J. and Olsson, A. G. (1984) Atherosclerosis 53, 77-84

7 Loesberg, C., Van Wijk, R., Zandbergen, J., Van Aken, W. G., Van Mourik, J. A. and De Groot, P. H. G. (1985) Exp. Cell. Res. 160, 117-121

8 Hoover, R. L., Rosenberg, R., Haering, W. and Karnovsky, M. J. (1980) Circ. Res. 47, 578-583

9 Heyns, A. P., Eldor, A., Vlodavsky, I., Kaiser, N., Fridman, R. and Panet, A. (1985) Exp. Cell. Res. 161, 297-303

10 Assoian, R. K. and Sporn, M. B. (1986) J. Cell. Biol. 102, 1217-1221

11 Fukumoto, Y., Kawahara, Y., Kariya, K., Araki, S., Fukuzaki, H. and Takai, Y. (1988) Biochem. Biophys. Res. Commun. 157, 337-341

12 Kimes, B. W. and Brandt, B. I. (1976) Exp. Cell. Res. 98, 349-366

13 Cascieri, M. A., Chicchi, G. G., Hayes, N. S and Slater, E. E. (1986) Circ. Res. 59, 171-177

14 Nakaki, T., Nakayama, M. and Kato, R. (1989) Eur. J. Pharmacol. 189, 347-353 
15 Garg, U. C. and Hassid, A. (1989) J. Clin. Invest. 83, 1774-1777

16 Ko, F. N., Wu, C. C., Kuo, S. C. and Teng, C. M. (1994) Blood, 84, 4226-4233

17 Yoshina, S. and Kuo, S. C. (1978) Yakugaku Zasshi 98, 204-208

18 Grainger, D. J., Hesketh, T. R., Weissberg, P. L. and Metcalfe, J. C. (1992) Biochem. J. 283, 403-408

19 Grainger, D. J., Hesketh, T. R., Weissberg, P. L. and Metcalfe, J. C. (1991) Biochem. J. 277, 145-151

20 Morinelli, T. A., Zhang, L. M., Newman, W. H. and Meier, K. E. (1994) J. Biol. Chem. 269, 5693-5698

21 Kariya, K. I., Kawahara, Y., Araki, S. I., Fukuzaki, H. and Takai, Y. (1989) Atherosclerosis 80, 143-147

22 White, A. A. and Zenser, T. V. (1971) Anal. Biochem. 41, 372-396

23 Gerzer, R., Hamet, P., Ross, A. H., Lawson, J. A. and Hardman J. G. (1983) J. Pharmacol. Exp. Ther. 226, 180-186

24 Bradford, M. M. (1976) Anal. Biochem. 72, 248-254

25 Thompson, W. J. and Appleman, M. M. (1971) Biochemistry 10, 311-316

26 Moore, J. B., Fuller, J. B. L., Falotico, R. and Tolman, E. L. (1985) Thromb. Res. 40, 401-411

27 March, K. L., Wilensky, R. L., Roeske, R. W. and Hathaway, D. R. (1993) Circ. Res. 72, 413-423

28 Nemecek, G. M., Coughlin, S. R., Handley, D. A. and Moskowitz, M. A. (1986) Proc. Natl. Acad. Sci. U.S.A. 83, 674-678
29 Kondo, T., Konishi, F., Inui, H. and Inagami, T. (1993) J. Biol. Chem. 268, 4458-4464

30 Schwartz, S. M., Campbell, G. R. and Campbell, J. H. (1986) Circ. Res. 58, 427-444

31 Clowes, A. W., Reidy, M. A. and Clowes, M. M. (1983) Lab. Invest. 49, 327-333

32 Assender, J. W., Southgate, K. M., Hallet, M. B. and Newby, A. C. (1992) Biochem. J. 288, 527-532

33 Yang, W., Ando, J., Korenaga, R., Toyo-oka, T. and Kamiya, A. (1994) Biochem. Biophys. Res. Commun. 203, 1160-1167

34 Ziche, M., Morbidelli, L., Masini, E., Granger, H., Geppetti, H. and Ledda, F. (1993) Biochem. Biophys. Res. Commun. 192, 1198-1203

35 Kase, H., Iwahashi, K., Nakanishi, S., Matsuda Y., Yamada, K., Takahashi, M. Murakata, C., Sato, A. and Kaneto, M. (1987) Biochem. Biophys. Res. Commun. 142, 436-443

36 Yu, S. M., Chen, C. C., Huang, Y. L., Tsai, C. W., Lin, C. H., Huang, T. F. and Teng, C. M. (1990) Eur. J. Pharmacol. 187, 39-47

37 Friedman, D. L. (1976) Physiol. Rev. 56, 652-708

38 Jonzon, B., Nilsson, J. and Fredholm, B. B. (1985) J. Cell. Physiol. 124, 451-456

39 Owen, N. E. (1986) Am. J. Physiol. 250, C584-C588

40 Noack, E. and Feelisch, M. (1989) J. Cardiovasc. Pharmacol. 14 (Suppl. 11), S1-S5

41 Edwards, D. H., Griffith, T. M., Ryley, H. C. and Henderson, A. H. (1986) Cardiovasc. Res. 20, 549-556

Received 1 August 1994/8 November 1994; accepted 17 November 1994 